\title{
Analisis Dampak Pemberdayaan Masyarakat Peternak Sapi Perah terhadap Penyerapan Tenaga Kerja Melalui Koperasi Peternak Garut Selatan (KPGS)
}

\author{
${ }^{1}$ Rd. Ade Purnawan, ${ }^{2}$ Rohimat Nurhasan \\ Universitas Garut \\ Email: ${ }^{1}$ rdadepur@gmail.com, ${ }^{2}$ nurhasanr@gmail.com
}

\begin{abstract}
This study aims to analyze the impact of community empowerment conducted by Koperasi Peternak Garut Selatan (KPGS) on labor absorption and productivity, especially in cooperative working areas. In this study the authors used descriptive explanatory method with respondents of 94 members of KPGS. The results of data processing shows that the empowerment variable has a positive effect on the variable of labor absorption and productivity variables.
\end{abstract}

Keywords: Empowerment, Employment Absorption, Productivity, Cooperative.

Abstrak. Penelitian ini bertujuan untuk menganalisis dampak pemberdayaan masyarakat yang dilakukan Koperasi Peternak Garut Selatan (KPGS) terhadap penyerapan tenaga kerja dan produktivitas, khususnya di wilayah kerja koperasi.Dalam penelitian ini penulis menggunakan metode deskriptif eksplanatori dengan responden sejumlah 94 orang anggota KPGS. Hasil pengolahan data menunjukkan bahwa variabel pemberdayaan berpengaruh positif terhadap variabel penyerapan tenaga kerja dan variabel produktivitas.

Kata Kunci: Pemberdayaan, Penyerapan tenaga kerja, Produktivitas, Koperasi.

\section{A. PENDAHULUAN}

Pada dasarnya pemberdayaan (empowerment) mengandung makna segala kegiatan atau setiap proses yang dilakukan sehingga dapat membuat masyarakat berdaya.Terdapat beberapa faktor yang membuat masyarakat dapat berdaya dan berkembang, karena diyakini setiap anggota masyarakat memiliki potensi, gagasan dan kemampuan yang dapat membawa masyarakatnya menuju ke arah yang lebih baik. Akan tetapi, tidak sedikit pula faktor-faktor yang dapat menghambat kemandirian masyarakat sehingga berpengaruh terhadap perkembangannya.

Diperlukan dorongan atau stimulus berupa gagasan, ide dan lainnya untuk dapat menumbuhkan kemandirian masyarakatdi dalam komunitasnya. Sehingga diharapkan dorongan dan stimulus tersebut dapat menyadarkan kembali anggota masyarakat untuk dapat melakukan peran dan fungsinyadalam kerangka menunjang pembangunan masyarakatnya.

Ketenagakerjaan merupakan salah satu hal penting yang menjadi perhatian serius setiap pemerintahan dalam proses pembangunan. Penyerapan tenaga kerja berdampak besar terhadap berhasil tidaknya pembangunan.Todaro (2000) berpendapat bahwa dalam proses pembangunan, beberapa tujuan yang harus dicapai yaitu pertumbuhan ekonomi, penanganan ketimpangan pendapatan, serta pengentasan kemiskinan dengan melakukan perubahan mendasar atas struktur sosial, sikap-sikap masyarakat, dan institusi nasional. 
Kabupaten Garut memiliki luas wilayah $306.519 \mathrm{Ha}$, dengan wilayah administratif terdiri dari 42 kecamatan, 21 kelurahan dan 421 desa yang terbagi kedalam 15.606 SLS terkecil (RT). Pada tahun 2014 Kabupaten Garut memiliki jumlah penduduk sebanyak 2.526.186 jiwa yang terdiri dari 1.274 .098 penduduk lakilaki dan 1.252.088 penduduk perempuan. Jumlah penduduk Kabupaten Garut dalam 10 tahun terakhir mengalami pertumbuhan rata-rata sebesar 1,59\% per tahun (Badan Pusat Statistik (BPS) Kabupaten Garut).

Di Kabupaten Garut pada tahun 2014 terjadi peningkatan angkatan kerja baru, sehingga pada tahun tersebut total angkatan kerja baru mencapai 1.022.545 jiwa, atau 59,05\% dari total penduduk usia kerja yang mencapai 1.731.567 jiwa. Tingkat partisipasi angkatan kerja (TPAK) di Kabupaten Garut mengalami peningkatan selama periode 2008-2014, yakni sebesar $12,93 \%$.

Sedangkan bila dilihat dari sisi pasar tenaga kerja terjadi peningkatan penawaran tenaga kerja lebih tinggi dibandingkan dengan kenaikan jumlah angkatan kerja. Sehingga, kondisi demikian menyebabkan penurunan tingkat pengangguran terbuka (TPT) yang cukup signifikan di tahun 2014, yakni dari $10,98 \%$ menjadi $7,71 \%$. Walaupun terlihat masih cukup tinggi, tetapi apabila dibandingkan dengan angka provinsi, TPT Kabupaten Garut relatif rendah, dimana pada tahun yang sama TPT Jawa Barat mencapai 8,45\%.

Koperasi Peternak Garut Selatan (KPGS) sebagai bagian dari masyarakat yang merupakan lembaga yang didirikan oleh masyarakat peternak sapi perah bertujuan untuk memberdayakan anggotanya agar mampu mandiri secara ekonomi yang pada akhirnya akan berimplikasi terhadap penyerapan tenaga kerja.

Koperasi Peternak Garut Selatan
(KPGS) adalah suatu badan usaha yang kegiatan utamanya bergerak dibidang usaha sapi perah/susu segar yang dikelola oleh anggota koperasi yang merupakan peternak sapi perah, dikelola secara mandiri oleh koperasi untuk akhirnya menghasilkan produkproduk olahan susu sapi.

Kegiatan usaha utama atau core business KPGS adalah menampung hasil produksi berupa susu segar dari para anggota peternaknya, kemudian menjualnya ke PT. Indolakto, PT. Indomilk, PT. Danone Dairy Indonesia dan PT. Ultrajaya. Unit bisnis inilah yang paling menonjol peranannya dalam menunjang kelangsungan hidup, baik kelangsungan hidup KPGS sebagai sebuah badan usaha, maupun kelangsungan hidup anggota peternak. Selain itu, unit bisnis ini jugadapat mendorong pengembangan unit usaha penunjang lainnya, seperti unit usaha makanan ternak (pakter) dan unit usaha warung serba ada (waserda).

Hal inilah yang menarik perhatian penulis untuk meneliti pengaruh pemberdayaan masyarakat peternak sapi perah melalui KPGS Kecamatan Cikajang terhadap penyerapan dan produktivitas tenaga kerja.

\section{B. KAJIAN LITERATUR}

\section{Pemberdayaan}

Dalam konsep pemberdayaan, menurut Prijono dan Pranarka (1996), manusia adalah subyek dari dirinya sendiri.Pemberdayaan merupakan sebuah proses dimana masyarakat didorong, dimotivasi, dan proses lainnya sehingga dapat berdaya (memiliki kemampuan) dalam menentukan pilihan hidupnya. Kelompok masyarakat yang tertinggal adalah objek dari proses pemberdayaan tersebut. 
Menurut Sumodiningrat (1999), bahwa pemberdayaan masyarakat adalah sebuah proses untuk mewujudkan potensi kemampuan yang dimiliki masyarakat melalui sebuah proses memandirikan masyarakat itu sendiri. Proses pemberdayaan tersebut melibatkan dua kelompok masyarakat yaitu kelompk masyarakat yang harus diberdayakan dan kelompok lain adalah pihak yang melakukan pemberdayaan.

Mubyarto (1998) menekankan bahwa titik berat pemberdayaan masyarakat adalah pemberdayaan ekonomi rakyat.Penciptaan peluang usaha, mengembangkan sumberdaya manusia di pedesaan, pengembangan usaha-usaha kreatif dan lain-lain, adalah upaya-upaya yang dapat dilakukan dalam proses pemberdayaan. Masyarakat didorong untuk dapat mandiri menentukan keinginannya dalam jenis usaha, kondisi wilayah yang pada gilirannya dapat menciptakan lembaga dan sistem pelayanan dari, oleh dan untuk masyarakat setempat.

Hal yang mula-mula harus dilakukan dalam proses pemberdayaan adalah dengan menciptakan suasana atau iklim yang dapat menstimulus masyarakat berkembang. Inilah maknanya bahwa setiap individu dalam masyarakat memiliki potensi yang dapat dikembangkan atau dengan kata lain, tidak ada masyarakat yang tanpa daya (kemampuan) sama sekali.

Langkah selanjutnya dari proses pemberdayaan adalah dengan memperkuat potensi atau daya yang dimiliki oleh masyarakat tersebut. Langkah-langkah tersebut diantaranya berkaitan dengan penyediaan masukan (input) berupa sumberdaya, serta membuka akses terhadap beberapa kemungkinan peluang (opportunities) yang akan membuat masyarakat menjadi makin berdaya (Kartasasmita, 1996).

Pemberdayaan yang dimaksudkan dalam penelitian ini adalah pemberdayaan sektor informal, khususnya kelompok masyarakat peternak sapi perah sebagai bagian dari masyarakat yang membutuhkan penanganan/pengelolaan tersendiri, baik dari pihak pemerintah maupun pihak-pihak lain, terkait dengan upaya meningkatkan kualitas sumberdaya yang mereka miliki. Hal ini dilakukan dengan harapan akan mendorong kesempatan kerja serta peningkatan pendapatan/profit usaha sehingga pada akhirnya upaya pemberdayaan tersebut mampu memberikan kontribusi baik secara langsung maupun tidak langsung terhadap pembangunan.

\section{Koperasi}

Berdasarkan Undang-Undang No. 25 Tahun 1992, Bab I, Pasal 1, Ayat 1, Koperasi adalah badan usaha yang beranggotakan orang seorang atau badan hukum koperasi dengan melandaskan kegiatannya berdasarkan prinsip koperasi sekaligus sebagai gerakan ekonomi rakyat yang berdasar atas asas kekeluargaan.

Definisi di atas menggunakan pendekatan yuridis formal atau dalam khasanah ilmu koperasi disebut pendekatan esensialis. Pendekatan lain yang dapat digunakan untuk memahami koperasi adalah pendekatan nominalis, yang mendefinisikan koperasi berdasarkan ciri-ciri universal. Ciri-ciri tersebut adalah sebagai berikut (Dulfer, 1974; Hanel/Mukner, 1976) :

1. Sejumlah individu yang bersatu dalam suatu kelompok atas dasar sekurang-kurangnya satu kepentingan atau tujuan yang sama (kelompok koperasi)

2. Anggota-anggota kelompok koperasi secara individual bertekad 
mewujudkan tujuannya, yaitu memperbaiki situasi ekonomi dan sosial mereka, melalui usaha-usaha bersama (joint action) dan saling membantu (swadaya kelompok koperasi)

3. Sebagai instrumen (wahana) untuk mewujudkannya adalah suatu perusahaan yang dimiliki dan dikelola secara bersama (perusahaan koperasi)

4. Perusahaan koperasi tersebut ditugaskan untuk menunjang kepentingan para anggota kelompok koperasi itu, dengan cara menyediakan/menawarkan barang dan jasa yang dibutuhkan oleh para anggota dalam kegiatan ekonominya, yaitu dalam perusahaan/usaha atau rumah tangganya masing-masing (tujuan/ tugas atau prinsip promosi anggota)

Secara umum, koperasi bertujuan mewujudkan kesejahteraan anggota pada khususnya dan masyarakat pada umumnya serta ikut membangun tatanan perekonomian nasional dalam rangka mewujudkan masyarakat yang maju, adil dan makmur berdasarkan Pancasila dan Undang-Undang Dasar 1945.(Pasal 3, Undang-Undang No. 25 Tahun 1992).

Secara khusus tujuan koperasi adalah memajukan kepentingan anggotanya (ekonomi, sosial, budaya), sebagaimana terlihat pada definisi para nominalis, dan definisi koperasi berdasarkan ICA.

Jadi, pada penelitian ini pengertian pemberdayaan adalah upaya untuk memandirikan masyarakat lewat perwujudan potensi kemampuan yang mereka miliki yang dilakukan oleh Koperasi Peternak Garut Selatan. Pemberdayaan yang dimaksud dapat berupa pemberian bantuan KPGS terhadap anggota peternak sapi perah.

\section{Penyerapan Tenaga Kerja}

Dalam konteks ketenagakerjaan, penduduk suatu negara dapat dikategorikan menjadi dua yaitu tenaga kerja dan bukan tenaga kerja. Tenaga kerja dimaknai sebagai penduduk yang berusia kerja (15 tahun ke atas), sesuai dengan UU Ketenagakerjaan No. 13 Tahun 2003. Penduduk usia kerja dikelompokkan menjadi angkatan kerja dan bukan angkatan kerja. Penduduk pada kelompok angkatan kerja dimaknai sebagai penduduk yang termasuk usia kerja yang mempunyai pekerjaan, atau mempunyai pekerjaan namun untuk sementara tidak sedang bekerja dan yang mencari pekerjaan.Sedangkan penduduk pada katagori bukan angkatan kerja adalah penduduk dalam usia kerja yang tidak bekerja atau sedang tidak bekerja atau tidak mempunyai pekerjaan disebabkan karena memiliki kegiatan lain seperti : sekolah, mengurus rumah tangga serta menerima pendapatan tapi bukan merupakan imbalan langsung atas jasa kerjanya misal pensiunan.

Tenaga kerja adalah salah satu dari faktor produksi yang penting, karena produktivitas dari faktor produksi lain bergantung pada produktivitas tenaga kerja dalam menghasilkan produksi. Selain itu, tenaga kerja adalah penggerak pembangunan.Pengertian tenaga kerja menurut Badan Pusat Statistik (BPS) yaitu penduduk usia kerja, yaitu penduduk yang berusia dari 15-64 tahun.

Sedangkan konsep bekerja menurut BPS adalah seluruh kegiatan dalam konteks pemenuhan ekonomi yang dilakukan oleh seseorang dengan tujuan untuk memperoleh dan membantu memperoleh pendapatan (penghasilan) atau keuntungan,dengan meliputi rentang waktu minimal satu 
jam (tidak terputus)dalam seminggu yang lalu. Kegiatan tersebut termasuk pula didalamnya adalah kegiatan pekerja keluarga yang biasanya tanpa upah yang membantu dalam suatu usaha atau kegiatan perkonomian lainnya.

Dalam proses penggunaan tenaga kerja selalu mengandung kepaduan antara kegiatan fisik dan mental. Barthos (1999) mengemukakan bahwa tenaga kerja dapat dibedakan menjadi dua, yaitu:

Tenaga kerja fisik, yaitu tenaga kerja yang bekerja didasarkan atas kerja otot atau anggota badan atau kekuatan jasmaniah yang berupa kekuatan tangan dan kaki semata.

Tenaga kerja yang berdasarkan pikiran. Tenaga kerja seperit ini lebih mengandalkan kerja otak, akal dan pikirannya lebih dari kegiatan fisiknya.

Sedangkan Basu Swastha (2000) membagi tenaga kerja menjadi beberapa bagian sesuai dengan fungsinya, yaitu :

1. Tenaga Kerja Eksekutif adalah tenaga kerja yang memiliki fungsi dan tugas seperti : mengambil keputusan, sebagai pelaksana fungsi organik manajemen kelompok, merencanakan, mengorganisasikan, mengarahkan, mengordinir dan mengawasi.

Tenaga Kerja Operatif yaitu tenaga kerja yang memiliki fungsi sebagai pelaksana yang melaksanakan tugastugas tertentu yang dibebankan kepadanya. Tenaga kerja operatif dikategorikan menjadi tiga bagian, yaitu:

a. Tenaga kerja terampil (skilled labour)

b. Tenaga kerja setengah terampil (semi skilled labour)

c. Tenaga kerja tidak terampil (unskilled labour)
Dasar perkiraan kesempatan kerja adalah rencana investasi dan target hasil yang direncanakan atau secara umum rencana pembangunan. Setiap kegiatan (baik kegiatan ekonomi maupun kegiatan non ekonomi) memiliki daya serap yang berbedabedaterhadap tenaga kerja, baik ditinjau dari sisi kuantitas maupun dari sisi kualitas. Daya serap tersebut berbeda secara sektoral disebabkah oleh banyak faktor seperti penggunaan teknologi dan lain-lain. Sektor maupun sub sektor yang dibangun dengan metode padat karyamenyebabkan kesempatan kerja yang relatif besar dan tidak terlalu terikat pada persyaratan keterampilan yang cukup tinggi, dibandingkan pada sektor yang menggunakan teknologi yang tinggi.

Dalam memperkirakan kesempatan kerja, perkiraan daya serap tenaga kerja baik dari sektor serta sub sektor ekonomi amatlah penting (Payaman J. Simanjuntak, 1985).

2012) $\begin{array}{rr}\text { Kuncoro (dalam } & \text { Fadlillah, } \\ \text { mengemukakan } & \text { tentang }\end{array}$ pengertian penyerapan tenaga kerja yaitu seluruh lapangan pekerjaan yang telah terisi yang juga mencerminkan sejumlah penduduk yang bekerja atau dapat disebut dengan angkatan kerja yang telah bekerja. Jumlah angkatan kerja yang tersebar (diserap) pada berbagai sektor ekonomi tersebut diakibatkan adanya permintaan tenaga kerja.

Sedangkan, menurut Tohar (2007: 10) penyerapan tenaga kerja adalah suatu kondisi yang menggambarkan tersedianya pekerjaan atau lapangan pekerjaan yang dapat diisi oleh para pencari kerja sehingga tenaga kerja dapat melakukan tugas sebagaimana mestinya.

Sudarsono (dalam Putra, 2012) mengemukakan bahwa penyerapan 
(2004) mengungkapkan bahwa produktivitas kerja di ukur melalui faktor-faktor sebagai berikut :(1) kuantitas kerja, yaitusuatu hasil akhir yang dicapai oleh pekerja dalam jumlah tertentu dengan perbandingan standar yang dibuat atau ditetapkan oleh perusahan, (2) kualitas kerja yaitu suatu standar hasil yang berkaitan dengan kualitas suatu produk yang dihasilkan oleh pekerja. Kualitas kerja dalam hal ini merupakan suatu kemampuan pekerja dalam menyelesaikan pekerjaan secara teknis dengan memperbandingkan hasil pekerjaan tersebut dengan standar yang ditetapkan oleh perusahaan, dan (3) ketepatan waktu yaitu apabila suatu aktivitas (pekerjaan) diselesaikan oleh pekerja pada awal waktu yang ditentukan, serta memaksimalkan waktu yang tersedia untuk aktivitas lain.Ketepatan waktu diukur dari persepsi karyawan terhadap suatu aktivitas yang disediakan diawal waktu sampai menjadi output.

Dengan kata lain, jika diformulasikan, maka produktivitas dapat diperjelas dengan formula sebagai berikut :

$$
P=\frac{O}{I}
$$

Dimana:

$\mathrm{P}=$ Produktivitas;

$\mathrm{O}=$ Output;

$\mathrm{I}=$ Input

Dalam penelitian ini, dimensi produktivitas akan diukur dari perbandingan tingkat input dan tingkat output. Input akan diambil dari jumlah jam kerja dan jumlah sapi yang siap panen sedangkan output akan diambil dari data susu yang dihasilkan dan pendapatan peternak.

\section{METODE PENELITIAN}

Dalam penelitian ini penulis menggunakan metode deskriptif eksplanatori.Metode deskriptif eksplanatori pada dasarnya merupakan suatu metode yang dapat digunakan untuk mendeskripsikan atau memberikan gambaran terhadap objek penelitian melalui data sampel atau populasi sebagaimana adanya kemudian dilakukan analisis dan dibuat kesimpulan yang berlaku umum.

Sedangkan desain penelitiannya adalah penelitian korelasional. Penelitian korelasional merupakan suatu metode yang menggambarkan pendekatan umum yang berfokus pada penaksiran pada kovariasi diantara variabel yang muncul secara alami (Emzir, 2012: 37).

Sementara statisitik yang digunakan adalah statitistik inferensial. Menurut Sugiono (2011) statistik inferensial adalah statistik yang digunakan untuk menganalisis data sampel. Selanjutnya, dari hasil analisis data sampel tersebut dapat digunakan sebagai alat untuk men-generalisasi hasil yang dapat diterapkan pada populasi dimana sampel diambil.

Karena jenis data yang dipakai adalah data interval maka statistik yang dipakai adalah statistik parametris. Hal ini didukung oleh pendapatnya Sugiyono (2011) yang mengatakan bahwa statistik parametris digunakan untuk menganalisis data interval dan rasio.

Penelitian ini berlokasi di wilalyah kerja Koperasi Peternak Garut Selatan yang tersebar di beberapa kecamatan diantaranya : Kecamatan Pamulihan, Kecamatan Cikajang, Kecamatan Banjarwangi, Kecamatan Cihurip, dan Kecamatan Cisurupan. Waktu penelitian berkisar antara bulan Juni - Agustus 2017.

Populasi adalah keadaan dari keseluruhan subyek penelitian, sedangkan sampel adalah bagian dari 
jumlah dan karakteristik yang dimiliki oleh populasi tersebut (Sugiyono, 2011).Dalam penelitian ini populasinya adalah seluruh anggota Koperasi Peternak Garut Selatan yang tersebar di 5 kecamatan di Kabupaten Garut, yaitu sebanyak 1629 anggota koperasi peternak.

Dengan mempertimbangkan berbagai keterbatasan, seperti : tenaga, biaya dan waktu, maka penelitian ini menggunakan metode simple random sampling dengan pengambilan sampel menggunakan rumus slovin sebagai berikut :

$$
n=\frac{N}{1+N e^{2}}
$$

Dimana :

$\mathrm{n}=$ jumlah sampel

$\mathrm{N}=$ jumlah populasi

$\mathrm{e}=$ error level (tingkat kesalahan).

Dalam penelitian ini diambil tingkat error $10 \%$, jadi, sampel yang akan digunakan sebanyak :

$$
n=\frac{1629}{1+1629 \cdot 0,1^{2}}
$$

$n$

\section{= 94,21 dibulatkan menjadi 94 orang}

Jadi, dalam penelitian ini akan digunakan sebanyak 94 orang sampel anggota Koperasi Peternak Garut Selatan (KPGS). Sejumlah responden tersebut akan diambil secara acak (random) dalam 5 wilayah kerja koperasi.

Dalam penelitian ini, data-data yang diperlukan akan dimabil dengan cara penelitian lapangan (field research) dan studi pustaka/dokumentasi (library reseach) yaitu data yang diperoleh secara langsung dan tidak langsung dengan meninjau pelaksanaan pemberdayaan masyarakat melalui KPGS mengenai hal-hal yang ada hubungannya dengan permasalahan melalui :
1. Studi Lapangan

a. Observasi, yaitu melakukan pengamatan atau monitoring secara langsung pada objek penelitian dengan mencatat dan men-checklist secara sistematis hal-hal yang berkaitan dengan keperluanpenelitian.

b. Angket, yaitu cara pengumpulan data dengan memberikan kuesioner atau formulir berisi sejumlah pertanyaan dan pernyataan yang berkaitan dengan pelaksanaan pemberdayaan masyarakat melalui KPGS.Setiappertanyaan disertai dengan alternatif jawaban sehingga responden dapat langsung memilih sesuai dengan pilihannya.

c. Wawancara, yaitu melakukan tanya jawab langsung atau dialog dengan responden yang menjadi objek penelitian guna memperoleh data yang tidak dapat dilakukan melalui observasi maupun studidokumentasi.

Studi dokumentasi yaitu memperoleh data sekunder dari laporan-laporan kegiatan, literatur dan dokumen yang berkaitan dengan masalah-masalahpenelitian.

Secara teoritis menurut Sugiyono (2007) variabel dapat didefinisikan sebagai atribut seseorang atau objek yang mempunyai "variasi" antara satu orang dengan yang lain atau satu objek dengan objek yang lain.

Operasional variabel menghadirkan variasi dari variabel penelitian yaitu variabel bebas (variabel independen) dan variabel terikat (variabel dependen).Variabel bebas merupakan variabel perlakuan atau sengaja diolah untuk diketahui intensitasnya atau pengaruhnya terhadap variabel terikat, sedangkan variabel terikat adalah variabel yang timbul akibat variabel bebas atau respon dari variabel bebas. 
Adapun variabel-variabel dalam penelitian ini adalah sebagai berikut:

1. Variabel Bebas (X) yaitu pemberdayaan masyarakat yang dilakukan oleh KPGS. Variabel bebas (independent) merupakan variabel yang mempengaruhi atau yang menjadi sebab perubahan atau timbulnya variabel terikat (dependen).

2. Variabel terikat (Y) yaitu penyerapan tenaga kerja dan produktivitas tenaga kerja. Variabel terikat (dependen) merupakan variabel yang dipengaruhi atau yang menjadi akibat karena adanya variabel bebas (independen).

Teknik analisa yang digunakan adalah teknik analisa korelasional. Menurut Sugiyono (2011) analisis data adalah suatu proses mengelompokan data berdasarkan variabel dan jenis responden, mentabulasi data berdasarkan variabel dari seluruh responden, menyajikan data tiap variabel yang diteliti, melakukan perhitungan untuk menjawab rumusan masalah, dan melakukan perhitungan untuk menguji hipotesis yang telah diajukan.

Analisis

korelasional merupakan analisis untuk mencari hubungan antar variabel (bebas dan terikat) untuk memprediksikan sebuah kondisi yang telah ada. Tingkatan hubungan tersebut diungkapkan sebagai suatu koefisien korelasi. Dalam studi korelasional diperlukan penaksiran seberapa tepat hubungan dua variabel tersebut. Gay dalam Emzir (2012) menyebutkan bahwa ukuran korelasional yang tinggi mendekati koefisien korelasi 1.00 atau -1.00 . Semakin tinggi hubungan dua variabel semakin akurat prediksi yang didasarkan pada hubungan tersebut.

Pengujian hipotesis dilakukan secara langsung melalui pengujian hipotesis dengan menggunakan perhitungan regresi dan korelasi.Sehubungan dengan keterkaitan variabel penelitian, langkah-langkah yang dilakukan adalah sebagai berikut :

Menghitung nilai persamaan regresi dengan menggunakan pendekatan least square, yaitu suatu metode perhitungan yang meminimalkan nilai kesalahan (error) antara nilai $\mathrm{Y}$ yang sebenarnya dengan nilai Y hasil peramalan. Bentuk umum dari persamaan regresi linier ini adalah $: \hat{Y}=a+b x$

Di mana $\hat{Y}$ menunjukkan nilai peramalan dari variable $\hat{Y}$ (dependen) ber dasarkan nilai tertentu dari variable $x$ (independen). Sedangkan $a$ adalah nilai intercept atau merupakannilaikonstantayangmenunju

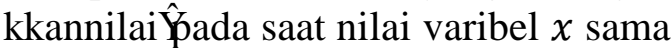
dengan nol. Kemudian $b$ menunjukkan slope atau merupakan perubahaan ratarata nilai Ŷntuk setiap perubahan nilai variable $x$. Lalu $x$ sendiri menunjukkan nilai tertentu dari variabel independen yang dipilih untuk menaksir nilai dari variabel dependen. Sehingga persamaan di atas dapat diartikan bahwa setiap pertambahan variabel $x$ sebesar 1 poin akan menambah nilai variabel Y sebesar bpoin.

\section{HASIL DAN PEMBAHASAN}

\section{Gambaran Umum Obyek Penelitian}

Objek penelitian dalam penelitian dosen pemula ini adalah Koperasi Peternak Garut Selatan (KPGS) Cikajang, yang beralamat di Jalan raya Cibodas, Kecamatan Cikajang Kabupaten Garut. Wilayah kerja KPGS meliputi lima kecamatan, terdiri dari : Pamulihan, Cikajang, Banjarwangi, Cihurip dan Cisurupan. 
Tabel 1.Data Kelompok Peternak Sapi Perah KPGS Tahun 2016

\begin{tabular}{llllll}
\hline No. & Nama Kelompok & Kec. & No. & Nama Kelompok & Kec. \\
\hline 1 & Panawa & Pamulihan & 19 & Giriawas & Cikajang \\
2 & Panda & Pamulihan & 20 & BabaknJolok & Cikajang \\
3 & Sumadra & Pamulihan & 21 & Sukarasa & Cikajang \\
4 & Nanjungsari & Pamulihan & 22 & Mekarmukti & Cikajang \\
5 & Rentengsari & Cikajang & 23 & Ciharus & Cikajang \\
6 & Kancah Nangkub & Cikajang & 24 & Mangunreja & Cikajang \\
7 & Simpang & Cikajang & 25 & Pamegatan & Cikajang \\
8 & Cimanyar I & Cikajang & 26 & Badega & Cikajang \\
9 & Cimanyar II & Cikajang & 27 & Sumber Sejahtera & Cikajang \\
10 & Jalan Lempeng & Cikajang & 28 & Pusaka Sumber Tani & Cikajang \\
11 & Cihideung & Cikajang & 29 & Karya Mekar & Cikajang \\
12 & Cijeruk & Cikajang & 30 & Mekar Saluyu & Cikajang \\
13 & Cimapag & Cikajang & 31 & Lemah Duhur & Banjarwangi \\
14 & Sirnamukti & Cikajang & 32 & Mitra Sejahtera & Banjarwangi \\
15 & Situgede & Cikajang & 33 & Pasir Pogor & Banjarwangi \\
16 & Negla & Cikajang & 34 & Hurip Mandiri & Cihurip \\
17 & Cibodas & Cikajang & 35 & Sawargi & Cisurupan \\
18 & Ngamplang & Cikajang & 36 & Padaringan & Cikajang \\
\hline
\end{tabular}

Tabel 2. Statistik Dasar Sampel Anggota Peternak Sapi Perah KPGS

\begin{tabular}{|c|c|c|c|}
\hline Keterangan & & Jumlah & $\%$ \\
\hline \multirow[t]{2}{*}{ Jenis Kelamin } & Laki-Laki & 78 & $83 \%$ \\
\hline & Perempuan & 16 & $17 \%$ \\
\hline \multirow[t]{3}{*}{ Umur } & $15-30$ & 10 & $11 \%$ \\
\hline & $31-50$ & 54 & $57 \%$ \\
\hline & $51-65$ & 30 & $32 \%$ \\
\hline \multirow[t]{5}{*}{ Pendidikan } & SD & 82 & $87 \%$ \\
\hline & SMP & 8 & $9 \%$ \\
\hline & SMU & 3 & $3 \%$ \\
\hline & DIPLOMA & 0 & $0 \%$ \\
\hline & $\mathrm{S} 1$ & 1 & $1 \%$ \\
\hline \multirow[t]{3}{*}{ Jumlah Tanggungan } & $1-2$ & 18 & $19 \%$ \\
\hline & $3-5$ & 69 & $73 \%$ \\
\hline & $\geq 6$ & 7 & $7 \%$ \\
\hline \multirow[t]{3}{*}{ Pendapatan per bulan } & Rata-rata & Rp. 2.977.447 & \\
\hline & Paling Tinggi & Rp. 8.000.000 & \\
\hline & Paling Rendah & Rp. 700.000 & \\
\hline \multirow{2}{*}{ Status Pekerjaan } & Utama & 79 & $84 \%$ \\
\hline & Sampingan & 15 & $16 \%$ \\
\hline
\end{tabular}


Lingkup usaha KPGS meliputi usaha susu sapi perah, usaha pakan ternak, usaha simpan pinjam, usaha mini market, usaha Cika Milk, Kredit Usaha Tani (KUT), unit usaha pangan dan pengelolaan sapi perah bantuan Kementerian Koperasi Republik Indonesia. Sampai saat ini, usaha susu sapi perah masih menjadi core bussiness KPGS dengan total omset lebih dari 41 milyar rupiah untuk tahun 2016.

Pada tahun 2016, KPGS memiliki anggota sebanyak 7.659 orang terdiri dari anggota laki-laki sebanyak 5.604 dan perempuan sebanyak 2.055 orang. Dari jumlah tersebut, yang menjadi anggota peternak sapi perah aktif adalah 1.629 orang yang terbagi ke dalam 36 kelompok peternak, yang tersebar di lima kecamatan wilayah kerja KPGS. Data kelompok peternak sapi perah KPGS dapat dilihat pada Tabel 1.

Dalam penelitian ini, responden yang dimintai keterangan adalah sejumlah 94 orang anggota KPGS yang merupakan anggota peternak sapi perah aktif. Data keragaan anggota KPGS secara umum dapat dilihat pada tabel 2.

Pada tabel 2 digambarkan bahwa jumlah responden sebanyak 94 orang terdiri dari 17\% adalah anggota peternak sapi perah KPGS berjenis kelamin perempuan, dan sisanya sebanyak $93 \%$ berjenis kelamin lakilaki. Rentang usia responden terbanyak ada di rentang usia 31-50 tahun, yaitu sebanyak 54 orang atau sekitar $57 \%$.

Dalam pendidikan, responden paling banyak berpendidikan Sekolah Dasar yaitu 82 orang atau sekitar $87 \%$ sedangkan yang lulus jenjang strata satu hanya terdapat 1 orang. Jumlah pendapatan per bulan dari responden paling tinggi adalah Rp. 8.000.000,00 per bulan dan paling rendah $\mathrm{Rp}$. $700.000,00$ dengan rata-rata pendapatan per bulan sebesar Rp. 2.977.447,00 per bulan. Selain itu, profesi sebagai peternak diakui responden sebagai pekerjaan utama adalah sebanya 79 orang atau sekira $84 \%$.

\section{Hubungan Pemberdayaan terhadap Penyerapan Tenaga Kerja}

Sebelum melakkukan regresi, terlebih dahulu dilakukan uji asumsi klasik yang terdiri dari : uji autokorelasi, uji heteroskedastisitas dan uji multikolinieritas. Hasil uji asumsi klasik menunjukkan bahwa data terbebas dari autokorelasi, heteroskedastisitas dan multikolinieritas. Setelah dilakukan regresi, maka hasilnya diperoleh sebagai berikut :

Model Summary ${ }^{\mathrm{b}}$

\begin{tabular}{|l|l|l|l|l|l|}
\hline Model & $\mathrm{R}$ & $\begin{array}{l}\mathrm{R} \\
\text { Square }\end{array}$ & $\begin{array}{l}\text { Adjusted } \\
\mathrm{R} \\
\text { Square }\end{array}$ & $\begin{array}{l}\text { Std. } \\
\text { Error } \\
\text { of the } \\
\text { Estimate }\end{array}$ & $\begin{array}{l}\text { Wurbin- } \\
\text { Watson }\end{array}$ \\
\hline 1 & ,232 &, 054 &, 044 & 51,48519 & 1,960 \\
\hline
\end{tabular}

a. Predictors: (Constant), Pemberdayaan(X)

b. Dependent Variable: PenyerapanTK(Y)

Tabel ini menjelaskan bahwa nilai korelasi $(\mathrm{R})$ sebesar 0,232 artinya terdapat hubungan antara variabel $\mathrm{X}$ terhadap Y sebesar 0,232. Dari tabel diatas digambarkan juga nilai koefisien determinasi sebesar 0,054 yang artinya bahwa pengaruh variabel bebas (pemberdayaan) terhadap variabel terikat (penyerapan tenaga kerja) sebesar $5,4 \%$.

ANOVA ${ }^{\text {a }}$
\begin{tabular}{|l|l|l|l|l|l|}
\hline Model & $\begin{array}{l}\text { Sum } \\
\text { of } \\
\text { Squares }\end{array}$ & $\begin{array}{l}\text { df } \\
\text { Sean } \\
\text { Square }\end{array}$ & F & Sig. \\
\hline Regression & 13887,747 & 1 & 13887,747 & 5,239 &, $024^{b}$ \\
1Residual & 243866,692 & 92 & 2650,725 & & \\
Total & 257754,439 & 93 & & & \\
\hline
\end{tabular}
a. Dependent Variable: PenyerapanTK(Y)
b. Predictors: (Constant), Pemberdayaan(X)


Dari tabel diatas diketahui bahwa nilai $\mathrm{F}$ hitung sebesar 5,239 dengan tingkat signifikansi sebesar $0,024<0,05$ maka model regresi dapat dipakai untuk memprediksi variabel penyerapan tenaga kerja, atau dengan kata lain, terdapat pengaruh variabel pemberdayaan terhadap variabel penyerapan tenaga kerja.

\section{Coefficients $^{\mathrm{a}}$}

\begin{tabular}{|c|c|c|c|c|c|}
\hline \multirow[t]{2}{*}{ Model } & \multicolumn{2}{|c|}{$\begin{array}{l}\text { Unstandardized } \\
\text { Coefficients }\end{array}$} & $\begin{array}{l}\text { Standardized } \\
\text { Coefficients } \\
\end{array}$ & \multirow[t]{2}{*}{$t$} & \multirow[t]{2}{*}{ Sig. } \\
\hline & B & Std. Error & Beta & & \\
\hline (Constant) & 46,470 & 12,957 & & 3,587 &, 001 \\
\hline $\begin{array}{l}\text { 1 Pemberdayaan } \\
\text { (X) }\end{array}$ & 9,743 & 4,256 &, 232 & 2,289 &, 024 \\
\hline
\end{tabular}

Dari tabel diatas, diketahui bahwa nilai konstanta (a) adalah 46,470 dan nilai variabel pemberdayaan (b) adalah 9,743 dengan demikian persamaan regresinya dapat ditulis :

$\mathrm{Y}=\mathrm{a}+\mathrm{bX}$

$Y=46,470+9,743 X$

Persamaan tersebut mengandung makna bahwa :

1. Konstanta sebesar 46,470 mengandung makna bahwa nilai konsisten variabel penyerapan tenaga kerja adalah sebesar 46,470 .

2. Koefisien regresi $X$ sebesar (negatif) 9,743 berarti bahwa setiap penambahan $1 \%$ nilai pemberdayaan maka nilai penyerapan tenaga kerja bertambah sebesar 9,743, dengan arah pengaruh positif.

Masih dari tabel tersebut, terlihat bahwa nilai signifikansi pemberdayaan $0,024<0,05$ mengandung makna bahwa variabel $X$ (pemberdayaan) berpengaruh terhadap variabel Y (Penyerapan Tenaga Kerja).

\section{Interpretasi}

Dari hasil analisis regresi diatas pemberdayaan ditemukan berpengaruh signifikan dan positif terhadap penyerapan tenaga kerja. Jika faktor- faktor lain dianggap konstan, maka dengan semakin meningkatnya pemberdayaan sebesar 1 satuan maka penyerapan tenaga kerja akan mengalami kenaikan sebesar 9,743. Hal ini dapat dijelaskan bahwa pemberdayaan yang dilakukan KPGS terhadap anggota, merupakan komponen yang sangat berperan penting dalam mendorong kegiatan produksi masyarakat (khususnya anggota peternak). Semakin besar dukungan (pemberdayaan) yang dilakukan KPGS terhadap anggota, maka semakin maka semakin tinggi upaya masyarakat anggota peternak untuk berusaha sehingga tingkat penyerapan tenaga kerja juga semakin tinggi. Demikian pula sebaliknya, apabila pemberdayaan yang dilakukan KPGS semakin berkurang, maka kecenderungan masyarakat peternak untuk berusaha juga semakin berkurang, sehingga berakibat terhadap rendahnya penyerapan tenaga kerja di sektor peternakan.

\section{Hubungan Pemberdayaan terhadap Produktivitas Tenaga Kerja}

Setelah dipastikan data tidak mengalami autokorelasi, heteroskedastisitas dan multikolinieritas, maka selanjutnya dilakukan regresi dengan hasil sebagai berikut :

Model Summary ${ }^{b}$

\begin{tabular}{|l|l|l|l|l|l|}
\hline Model & $\mathrm{R}$ & $\begin{array}{l}\mathrm{R} \\
\text { Square }\end{array}$ & $\begin{array}{l}\text { Adjusted } \\
\mathrm{R} \\
\text { Square }\end{array}$ & $\begin{array}{l}\text { Std. Error } \\
\text { of the } \\
\text { Estimate }\end{array}$ & \begin{tabular}{l} 
Durbin- \\
\hline 1
\end{tabular} \\
\hline
\end{tabular}

a. Predictors: (Constant), Pemberdayaan(X)

b. Dependent Variable: Produktivitas(Y)

Tabel ini menjelaskan bahwa nilai korelasi $(\mathrm{R})$ sebesar 0,305 artinya terdapat hubungan antara variabel $\mathrm{X}$ terhadap $\mathrm{Y}$ sebesar 0,305. Dari tabel diatas digambarkan juga nilai koefisien determinasi sebesar 0,093 yang artinya 
bahwa pengaruh variabel terikat (pemberdayaan) terhadap variabel terikat sebesar $9,3 \%$.

ANOVA $^{a}$

\begin{tabular}{|c|l|l|l|l|l|}
\hline Model & $\begin{array}{l}\text { Sum } \\
\text { of Squares }\end{array}$ & $\begin{array}{l}\text { Df } \\
\text { Square } \\
\text { Square }\end{array}$ & F & Sig. \\
\hline Regression & 17060,570 & 1 & 17060,570 & 9,406 &, $003^{b}$ \\
1Residual & 166865,217 & 92 & 1813,752 & & \\
Total & 183925,787 & 93 & & & \\
\hline
\end{tabular}

a. Dependent Variable: Produktivitas(Y)

b. Predictors: (Constant), Pemberdayaan(X)

Dari tabel diatas diketahui bahwa nilai $F$ hitung sebesar 9,406 dengan tingkat signifikansi sebesar $0,003<0,05$ maka model regresi dapat dipakai untuk memprediksi variabel penyerapan tenaga kerja, atau dengan kata lain, terdapat pengaruh variabel pemberdayaan terhadap variabel Produktivitas.

Coefficients $^{\mathrm{a}}$

\begin{tabular}{|l|l|l|l|l|l|}
\hline Model & \multicolumn{2}{|l|}{$\begin{array}{l}\text { Unstandardized } \\
\text { Coefficients }\end{array}$} & $\begin{array}{l}\text { Standardized } \\
\text { Coefficients }\end{array}$ & Sig. \\
\cline { 2 - 5 } & B & $\begin{array}{l}\text { Std. } \\
\text { Error }\end{array}$ & Beta & & \\
\hline $\begin{array}{l}\text { (Constant) } \\
\text { 1Pemberdayaan } \\
\text { (X) }\end{array}$ & 40,781 & 10,718 & & 3,805 & 000 \\
\hline
\end{tabular}

a. Dependent Variable: Produktivitas(Y)

Dari tabel diatas, diketahui bahwa nilai konstanta (a) adalah 40,781 dan nilai variabel pemberdayaan (b) adalah 10,798 dengan demikian persamaan regresinya dapat ditulis :

$\mathrm{Y}=\mathrm{a}+\mathrm{bX}$

$Y=40,781+10,798 X$

Persamaan tersebut mengandung makna bahwa :

1. Konstanta sebesar 40,781 mengandung makna bahwa nilai konsisten variabel Produktivitas adalah sebesar 40,781

2. Koefisien regresi $X$ sebesar (positif) 10,798 berarti bahwa setiap penambahan $1 \%$ nilai pemberdayaan maka nilai Produktivitas bertambah sebesar 10,798, dengan arah pengaruh positif.

Masih dari tabel tersebut, terlihat bahwa nilai signifikansi pemberdayaan
$0,003<0,05$ mengandung makna bahwa variabel $X$ (pemberdayaan) berpengaruh terhadap variabel Y (Produktivitas)

\section{Interpretasi}

Dari hasil analisis regresi diatas pemberdayaan ditemukan berpengaruh signifikan dan positif terhadap produktivitas tenaga kerja. Jika faktorfaktor lain dianggap konstan, maka dengan semakin meningkatnya pemberdayaan sebesar 1 satuan maka produktivitas tenaga kerja akan mengalami kenaikan sebesar 10,798. Hal ini dapat dijelaskan bahwa pemberdayaan yang dilakukan KPGS terhadap anggota, merupakan salah satu faktor yang sangat berperan penting dalam mendorong terciptanya produktivitas (khususnya anggota peternak). Semakin besar dukungan (pemberdayaan) yang dilakukan KPGS terhadap anggota, maka semakin maka semakin tinggi tingkat produktivitas anggota peternak. Demikian pula sebaliknya, apabila pemberdayaan yang dilakukan KPGS semakin berkurang, maka kecenderungan masyarakat peternak untuk produktif juga semakin berkurang.

\section{E. KESIMPULAN}

Berdasarkan hasil penelitian dan pembahasan yang dilakukan, terkait dengan pemberdayaan yang dilakukan KPGS terhadap penyerapan tenaga kerja, dapat ditarik beberapa kesimpulan sebagai berikut :

1. Sebagian besar anggota Koperasi Peternak Garut Selatan (KPGS) berusia pada usia produktif yaitu antara 31 sampai 50 tahun.

2. Sebagian besar anggota Koperasi Peternak Garut Selatan (KPGS) berpendidikan setingkat Sekolah Dasar.

3. Pendapatan tertinggi anggota 
koperasi adalah Rp. 8.000.000 per bulan, pendapatan terendah $\mathrm{Rp}$. 700.000 per bulan dengan rata-rata pendapatan per bulan adalah $\mathrm{Rp}$. 2.977.447.

4. Status pekerjaan anggota koperasi sebagai peternak sebagian besar adalah pekerjaan utama dan hanya sebagian kecil saja sebagai pekerjaan sampingan.

5. Hasil pengolahan data menunjukkan bahwa variabel pemberdayaan berpengaruh positif terhadap variabel penyerapan tenaga kerja dan variabel produktivitas.

Berdasarkan temuan penelitian mengenai dampak pemberdayaan KPGS Cikajang terhadap penyerapan tenaga kerja, maka saran-saran yang dapat diberikan adalah sebagi berikut:

1. Mengamati tingkat pendidikan anggota peternak yang sebagian berpendidikan rendah, disarankan kepada KPGS agar dapat mengembangkan program kerja terkait pendidikan. Program pendidikan tersebut dapat berupa pendidikan formal maupun informal, sehingga pengetahuan dan keterampilan peternak meningkat.

2. Pemberdayaan yang dilakukan oleh KPGS perlu didukung oleh banyak pihak, terutama pemerintah. Dukungan tersebut dapat berupa bantuan finansial maupun fasilitas/kemudahan bagi KPGS dalam mengembangkan programprogram pemberdayaannya. Pemberian bantuan tersebut diharapkan dapat memperluas dan meningkatkan kebutuhan tenaga kerja yang dengan sendirinya akan memberikan lapangan pekerjaan bagi masyarakat.

3. Bagi penelitian selanjutnya diharapkan penelitian ini dapat dijadikan bahan acuan dan perbandingan untuk melengkapi penelitian yang serupa di masa mendatang khususnya tentang ekonomi sumberdaya manusia terkait dengan upaya penciptaan lapangan kerja serta penyerapan tenaga kerja.

\section{DAFTAR PUSTAKA}

Badan Pusat Statistik, (2008), Analisis Kemiskinan 2008. Jakarta : Badan Pusat Statistik.

Badan Pusat Statistik, (2008), Indeks Pembangunan Manusia (IPM) Indonesia Tahun 2006 - 2007, Jakarta: Badan Pusat Statistik.

Badan Pusat Statistik, (2009) Indeks Pembangunan Manusia (IPM) Indonesia Tahun 2008 - 2009, Jakarta: Badan Pusat Statistik.

Badan Pusat Statistik, (2010), Survey Angkatan Kerja Nasional (SAKERNAS) Tahun 2006 s.d 2010, Jakarta: Badan Pusat Statistik.

Badan Pusat Statistik. (2006), Indator Industri Mikro dan Kecil Tahun 2001 s.d 2006, Jakarta: Badan Pusat Statistik.

Badan Pusat Statistik, (2016), Laporan Bulanan Data Sosial Ekonomi April 2016, Jakarta: Badan Pusat Statistik.

Badan Perencanaan Pembangunan Nasional, (2014), Rencana Pembangunan Jangka Menengah Nasional 2015-2019.Jakarta : BAPENAS.

Kartasasmita, G. (1996), Power and Empowermant:Sebuah Telaah Mengenal KonsepPemberdayaan Masyarakat, Badan Perencanaan Pembangunan Nasional, Jakarta.

Mubyarto (1998), Pembangunan ekonomi rakyat dan penanggulangan kemiskinan, 
kumpulan karangan, Jakarta.

Prijono dan Pranarka (1996), Pemberdayaan: Konsep, Kebijakan dan Implementasi, Center for Strategic and International Studies (CSIS), Jakarta.

Simanjuntak, Payaman. J. (1998), Pengantar Ekonomi Sumberdaya Manusia. Lembaga Penerbit FEUI. Jakarta. Sukirno, Sadono (2008), Mikro Ekonomi Teori Pengantar, PT. Raja Grafindo Persada, Jakarta.

Sugiyono (2007), Metode penelitian administrasi, Alfabeta, Bandung.

Sugiyono (2009), Statistika Untuk Penelitian, Pustaka Setia, Bandung.

Todaro S. (2000), Pembangunan Ekonomi di Dunia Ketiga, Edisi Ke-7, IPB Press, Jakata.

Undang-Undang No. 25 tahun 1992 tentang Perkoperasian 